\title{
WPS3573
}

\section{The Effects of Migration on Child Health in Mexico}

\author{
Nicole Hildebrandt and David J. McKenzie* \\ Department of Economics, \\ Stanford University
}

\begin{abstract}
This paper investigates the impact of international migration on child health outcomes in rural Mexico using a nationally representative demographic survey. Historic migration networks are employed as instruments for current household migration to the United States in order to correct for the possible endogeneity of migrant status. Children in migrant households are found to have lower rates of infant mortality and higher birthweights. We study the channels through which migration may affect health outcomes and find evidence that migration raises health knowledge in addition to the direct effect on wealth. However we also find that preventative health care, such as breastfeeding and vaccinations, is less likely for children in migrant households. These results provide a broader and more nuanced view of the health consequences of migration than is offered by the existing literature.
\end{abstract}

Keywords: migration; child health; infant mortality; health knowledge

JEL codes: O15, I12, F22

World Bank Policy Research Working Paper 3573, April 2005

The Policy Research Working Paper Series disseminates the findings of work in progress to encourage the exchange of ideas about development issues. An objective of the series is to get the findings out quickly, even if the presentations are less than fully polished. The papers carry the names of the authors and should be cited accordingly. The findings, interpretations, and conclusions expressed in this paper are entirely those of the authors. They do not necessarily represent the view of the World Bank, its Executive Directors, or the countries they represent. Policy Research Working Papers are available online at http://econ.worldbank.org.

\footnotetext{
\# Thanks to Gerardo Esquivel, Ernesto Schargrodsky, Miguel Urquiola, and participants at the Economia meeting in Costa Rica for helpful comments and suggestions.

* Corresponding author. E-mail: mcken@stanford.edu. Mailing address: Department of Economics, Stanford

University, 579 Serra Mall, Stanford, CA 94305-6072. Fax: (650) 725-5702.
} 


\section{Non-technical Summary}

This paper investigates the impact of international migration on child health outcomes in rural Mexico using a nationally representative demographic survey. Identification of the health effects of migration is complicated by the fact that migrants are not randomly drawn from the general population. Hildebrandt and McKenzie use historic migration networks as instruments for current household migration to the United States in order to correct for the selectivity of migrant status. Children in migrant households are found to have lower rates of infant mortality and higher birthweights than children in similar non-migrant households. They then study the channels through which migration may affect health outcomes and find evidence that migration improves child health through raising the health knowledge of mothers, in addition to the direct effect on health of higher wealth after migration. However they also find that preventative health care, such as breastfeeding and vaccinations, is less likely for children in migrant households. This research contributes more generally toward a broader view of the benefits and costs of migration for Mexico than that offered by the amount of remittances and number of migrants which frame much of the policy debate. More detailed analysis of the effects of migration on Mexican communities holds the potential for informing this policy debate and for understanding the likely consequences of any policy changes on Mexico's long-term development. The research provided in this paper enables clear identification of one such effect, showing migration has the potential to result in sizeable effects on child health. 


\section{Introduction}

Mexico has a long history of sending migrants to the United States, with the number of migrants growing over time. An equivalent of one-eighth of Mexico's labor force is now employed in the U.S. at any given time (Escobar Latapí et al., 1998), and remittances from these migrants were estimated as high as US\$14.5 billion in 2003, about 1.5\% of Mexico's GDP, and surpassing tourism and foreign direct investment as sources of foreign currency (Johnson and Contreras, 2004; Iliana Chávez, 2003). The flow of immigrants across the border is a central issue in U.S.Mexico relations and in the Guanajuato Proposal of February 2001 Presidents Vicente Fox of Mexico and George Bush of the United States pledged to work to create a process of orderly migration between the two countries, discussing proposals for a new temporary worker program and regularization of undocumented Mexicans in the U.S. ${ }^{1}$ Although security concerns following the terrorist attacks of September 11, 2001 halted this process, talks have resumed and President Bush began discussions of immigration reform within one week of election to a second term. ${ }^{2} \mathrm{~A}$ decade after NAFTA ushered in the free movement of goods and capital, labor mobility between the U.S. and Mexico remains a contentious and important issue.

A comprehensive understanding of the impact of migration on both sides of the border is needed for informed policy decisions. A large literature has focused on the consequences of immigration for the U.S. economy and U.S. workers. Borjas (1999) provides a survey of this literature and concludes that the economic benefits of immigration are relatively small on aggregate, but that there can be large distributional consequences. In particular, he famously argues that Mexican immigrants will be "negatively selected", meaning that they will tend to be predominantly lowskilled, and as a consequence, can have harmful effects on the lowest-skilled Americans. Economists have given relatively less attention to the impact of emigration on the sending country. However, the large prevalence of migration and size of the remittance flows are likely to have a significant impact on the Mexican economy and on Mexican households.

At an aggregate level, remittances may have short-run effects (on price and exchange rate

\footnotetext{
${ }^{1}$ See the Joint Communique issued by the U.S. Embassy in Mexico on June 22, 2001 "U.S.-Mexico Migration Talks and Plan of Action for Cooperation on Border Safety:, http://www.usembassy-mexico.gov/ejoint.html.

${ }^{2}$ See "Bush revives bid to legalize illegal aliens", The Washington Times, November 10, 2004, pages A1 and A15.
} 
levels), and long-run implications through their impact on productivity, economic inequality and poverty. At the micro level, early sociological studies emphasized that, for the most part, remittances were financing consumption and housing expenditures ${ }^{3}$, with limited dynamic effects. More recent research has found that migration is associated with higher levels of entrepreneurship and educational attainment of the children of migrants. ${ }^{4}$ This paper investigates further the impact of migration on human capital accumulation, focusing on child health outcomes. Child health outcomes are one important aspect of well-being and a key determinant of future productivity. In addition, our results provide evidence that the impact of migration exceeds just the direct effects of remittances, suggesting that consideration of the additional indirect benefits and costs of migration should be incorporated into the design of optimal migration policy.

Identification of the health effects of migration is complicated by the fact that migrants are not randomly drawn from the general population. Individuals in poor health are unlikely to be able to endure the process of crossing the border into the U.S., while the most prosperous and healthy rural Mexicans are less likely to find the benefits of illegal migration outweigh their other options in Mexico. Secondly, unobserved shocks such as crop failures or natural disasters may be both an impetus for migration and also result in worsening health conditions in the community. As a result, simple comparison of the health of migrants and non-migrants and their children will not provide reliable estimates of the effects of migration.

In this paper we use instrumental variables methods in order to account for these difficulties and provide credible estimates of the impact of migration on child health, allowing quantification of some of the benefits of migration for human capital accumulation in the sending country. A nationally representative demographic survey, the ENADID 1997 is used to provide a broad sample of migrants in rural communities with varying levels of migrant experience. Historic migration networks formed as a result of U.S. demand conditions and the pattern of development of the railroad system in the early 1900s are used as instruments for current levels of migration. Infant mortality rates and birth weights are the two child health outcomes considered in this

\footnotetext{
${ }^{3}$ See the literature review in Durand, Parrado and Massey (1996).

${ }^{4}$ See, for example, Hanson and Woodruff (2003) on education and Woodruff and Zenteno (2001) on microenterprises.
} 
paper. Our analysis finds that migration results in lower infant mortality rates and higher birth weights, and that failure to account for the selectivity of migration understates these gains. However, we also find that children in migrant households receive less preventative health inputs such as breastfeeding and vaccinations, which may have a detrimental impact on child health at older ages.

Having identified a positive overall effect of migration on child health, the paper then examines the principal channels through which migration works to improve health. The Grossman (1972) health production function approach is used to explain the likely channels through which migration can affect health outcomes. The first avenue is the direct effect of migration on income and wealth, through remittances and repatriated savings, which allows households to spend additional resources on food and health services. Secondly, through exposure to U.S. practices, migrants may gain health knowledge, allowing the same amount of financial resources to result in higher health attainment. Evidence is found that migration influences health outcomes through both of these mechanisms, raising both wealth and health knowledge.

Previous research on the interaction between migration and health is limited, and has tended to focus on differences between immigrants and the native-born, finding that migrants have worse health along a number of dimensions (see for example, Institute of Medicine, 1998), although that immigrants have surprisingly positive birth outcomes in the U.S. given their socioeconomic status. ${ }^{5}$ Analysis of the impact of migration on health outcomes in the sending region is much more limited, although recently two studies by sociologists have provided a first assessment. Kanaiaupuni and Donato (1999) use data from five Mexican states drawn from the Mexican Migration Project and find mixed effects of migration on infant mortality, suggesting that infant mortality increases in the early stages of the migration process before later declining. Frank and Hummer (2002) use the same ENADID data as this study to look at the effect of migration on the incidence of low birth weight, finding migrant children to be less likely to be underweight.

This paper builds on the two sociological studies and the existing literature in several important respects. Despite some discussion of possible selection bias, both Kanaiaupuni and Donato

\footnotetext{
${ }^{5}$ See the discussion and references in Frank and Hummer (2002).
} 
(1999) and Frank and Hummer (2002) choose to treat migration and remittances as exogenous, and as a consequence, it is likely that their estimated effects of migration are contaminated by selection bias. This paper uses a broad representative survey on both health measures studied by these authors, and explicitly deals with the endogeneity of migration. In addition we also consider the impact of migration on preventative health care. Previous research has found an important role for migration networks in providing information about the border crossing process (Espinosa and Massey, 1997) and about labor market opportunities in the U.S. (Munshi, 2003). Our paper provides a first investigation of the channels through which migration affects child health, and shows that the migration process can also result in improved health knowledge.

The remainder of the paper is structured as follows: Section 2 describes the ENADID data to be used in this study; Section 3 outlines the possible selection effects arising from migration and the instrumental variables method to be used; Section 4 estimates the impact of migration on fertility; Section 5 provides the main results of the effects of migration on infant mortality, birthweights, and preventative care; Section 6 investigates the channels through which migration impacts health outcomes and Section 7 concludes. An appendix provides further details on the construction of our measure of health knowledge.

\section{Data}

This paper uses data from the 1997 Encuesta Nacional de Dinámica Demográfica (ENADID) (National Survey of Demographic Dynamics) conducted by Mexico's national statistical agency, the Instituto Nacional de Estadística, Geografía e Informática (INEGI) in the last quarter of $1997 .^{6}$ The ENADID is a nationally representative demographic survey providing information about fertility and contraceptive practices, mortality, and migration. As will be detailed below, our analysis uses existing migration networks within each community in order to control for the non-random selection of migrants. The theoretical foundations of our work apply most directly to migration networks in rural communities, so we restrict our analysis to households in municipalities with populations of less than 100,000. All women aged 15 to 54 in each household are asked detailed questions about their fertility history. This gives us an initial

\footnotetext{
${ }^{6}$ A less comprehensive version of this survey was also undertaken in 1992 . We restrict ourselves to the 1997 wave since the 1992 wave contains less information on the child health measures used in this paper. Survey methodology and questionnaires are contained in INEGI (1999).
} 
sample of 42,527 women aged 15-54 living in 29,498 households located in 612 municipalities with populations less than 100,000 across all 32 states.

The ENADID enables us to construct two indicators of child health outcomes, which are infant mortality and birth weight. Infant mortality is defined in the standard way as a live birth dying during the first year of life. Mothers are asked more detailed information about their last two births since January $1^{\text {st }} 1994$, including the birth weight in kilograms of the baby. The initial sample is first used to examine whether women in migrant households are any more or less likely to have had a child since 1 January 1994 than women in non-migrant households. Finding no difference, we then condition on fertility and study infant mortality and birthweight for babies born after this date for the remainder of our analysis. After dropping missing values, this results in a main sample of 16,593 children born to 12,767 mothers in 12,396 households in 601 municipalities across all 32 states.

Data on birthweight are only available for 12,974 children due to both non-response and to this data only being collected for the last two children born since 1 January 1994 in each household. Furthermore, there appears to be some misreporting at the tails, with reported birthweights ranging from 0.5 kilograms to 6.5 kilograms. We trim the top and bottom $1 \%$ of birthweight observations to reduce this measurement error, leaving a sample of 12,117 children for our birthweight analysis. Non-reporting of birthweight is more common for less educated mothers, and conditional on education, slightly more prevalent in households without a migrant compared to households with a migrant. We will examine the sensitivity of our results to these reporting differences.

We classify households according to whether or not they had at least one member aged 15 and over who had migrated to the United States prior to 1 January 1994. We then are able to look at the impact of previous migrant experience on subsequent child health measures. This timing allows us to avoid concerns that child health outcomes and the migration decision are both the result of contemporaneous shocks, such as poor weather or disease outbreaks. The ENADID survey asks whether each member of the household has ever been to the United States in search of work, and whether they have ever lived in the U.S. These questions are asked of all household 
members who normally live in the household, even if they are temporarily studying or working elsewhere. An additional question asks whether any household members have gone to live in another country in the past five years. The survey asks migrants how long they have been living in their current location, the year of their last trip to the U.S., and the number of times they have been to the U.S., but does not ask the year of their first U.S. trip. We therefore classify individuals as having migrated prior to 1 January 1994 if their last trip was before this date, or if they have made at least two trips to the U.S. and their last trip was during 1994, or if they have made three (four) (five) trips to the U.S. and their last trip was during 1995 (1996) (1997). In addition to a binary classification into migrant and non-migrant households, we also construct household migration prevalence ratios, defined as the proportion of individuals aged 15 and over in the household who had been to the U.S. prior to 1 January 1994.

Table 1 presents summary statistics for the sample of households which had a child born since the start of 1994, along with t-tests which test for differences in means between migrant and nonmigrant households. Nineteen percent of households are seen to have at least one migrant, with nine percent of all adults in the sample having migrated to the United States at least once before 1994. The infant mortality rate in our sample is 23.7 per 1000 live births, which is close to the adjusted rate for all of Mexico in 1995 of 25.9 (PAHO, 1998). ${ }^{7}$ According to the international standard whereby low birthweight is classified as any weight less than 2.5 Kilograms, 7.5 percent of births in our sample are estimated to be underweight. This compares with a 1997 estimate of 8 percent for Mexico as a whole (UNICEF, 1997). Our data therefore appear to be well representative of general child health conditions in Mexico.

An initial comparison of migrant to non-migrant households reveals differences in child health outcomes, health inputs, and household characteristics. Children in migrant households are less likely to be born underweight, have higher average birthweights, and were more likely to have been delivered by a doctor. Infant mortality rates are higher in non-migrant households, but this difference is not statistically significant. However, children in non-migrant households appear to be slightly more likely to be breastfed and to have visited a doctor during their first year of life.

\footnotetext{
${ }^{7}$ Since our sample excludes urban areas, one would expect a higher infant mortality for our sample than for all of Mexico. The unadjusted national infant mortality rate was 17.5 per 1000 in 1995 , which perhaps is more directly comparable to our rates (PAHO, 1998).
} 
Migrant households are seen to be slightly larger in size and have older mothers with more health knowledge (to be described in Section 6). Mean household income is not statistically different between migrant and non-migrant households, but migrant households have better household infrastructure.

\section{Selection Effects and the Instrumental Variables Strategy}

The fundamental question which this paper seeks to address is whether these differences in child health outcomes between migrant and non-migrant households are a result of migration itself, whether they are caused by external conditions affecting both migration and child health, or whether they are simply a reflection of differences in the observable and unobservable characteristics of these households. External shocks, such as crop failure, disease outbreaks, or poor economic conditions in the sending community may lead to both higher rates of migration and worsened health conditions. As a result, one would tend to underestimate the healthimproving effects of migration. We look only at household migration decisions made prior to the birth of children in order to provide a first means of mitigating such a possibility, as well as using the instrumentation strategy below.

Migrants and non-migrants may differ in along a number of unobservable dimensions which may be correlated with child health outcomes. For example, parents who care more strongly about the health of their future children may migrate in order to increase the resources they will have for raising their children, and also will take better care of maternal and child health during pregnancy and infancy. A simple comparison of migrants and non-migrants would therefore overstate the health gains from migration. Individuals may also select into migration according to their health status. However, the direction of this selection effect is a priori unclear. The physical nature of migration itself, especially for undocumented migrants making hazardous border crossings, would tend to result in healthier individuals migrating. However, Borjas (1987) argues that migrants will be negatively selected from countries such as Mexico, which have higher inequality than the U.S., since the incentives for remaining in Mexico are greater for people in the top of the distribution. If more educated and wealthier people tend to have better health, then this factor would tend to result in migrants having poorer health than non-migrants. In practice migration is costly, both in terms of physical and material costs, and so Massey, Goldring and 
Durand (1994) note that the first migrants usually come from the lower middle ranges of the socioeconomic scale. As such it is not clear whether they will tend to be negatively or positively selected on average compared with non-migrant households.

We employ an instrumental variables strategy in order to separate the effect of migration from the impacts of these selection mechanisms. There is substantial evidence that migration networks play an important role in determining migration from Mexico. ${ }^{8}$ Following Woodruff and Zenteno (2001) and McKenzie and Rapoport (2004) we use historic state-level migration rates as an instrument for current migration stocks. The U.S. migration rate in 1924 for the state in which the household is located is taken from Foerster (1925). Figure 1 shows the geographical distribution, with the highest rates found in the West-Central states of Michoacán, Jalisco, Zacatecas and Durango, along with a couple of border states, Sonora and Coahuila. The lowest rates are not surprisingly found in the most southern states of Quintana Roo, Chiapas and Yucatán. Nevertheless, it is not simply the border states which have high migration, and one sees reasonable variation in migration rates among states of equal distance from the border. These historic rates can be argued to be the result of the pattern of arrival of railroads into Mexico coupled with U.S. demand conditions arising from restrictions on immigration from Asia at the turn of the century. Massey, Durand and Malone (2002) outline how these conditions led to some states having different initial migration rates than others. These initial migration networks then lowered the cost of further migration. This is argued by Massey, Goldring and Durand (1994, p 1496) to result in "a self-reinforcing process that...over time...becomes increasingly independent of the conditions that originally caused it".

As a consequence, by virtue of living in a community with high levels of early $20^{\text {th }}$ century migration, a household will have a higher likelihood of having a migrant member than an otherwise identical household living in a community with low initial migration rates. We therefore use the 1924 state migration rate as an instrument for whether a household had a migrant member in 1994 and for household migration prevalence. Table 2 shows the first-stage results for our instrumental variables estimation. Columns 1 and 2 show that the historic

\footnotetext{
${ }^{8}$ See Massey, Goldring and Durand (1994), Winters, de Janvry and Sadoulet (2001) and Munshi (2003) among others.
} 
migration rate is an extremely strong determinant of whether a household has a migrant member, with the F-statistic on the 1924 migration rate above 30. Therefore our estimation does not appear to be subject to weak instrument concerns.

\subsection{Threats to Instrument Validity}

Our identifying assumption is that the historic community migration rates, reflecting the pattern of early development of the railroad system in Mexico, do not affect child health outcomes over 70 years later apart from their influence through current migration. Our instrumental variables estimation relies on this exogeneity assumption, and therefore it is important to consider possible threats reasons to its validity. We consider two such threats. The first is that different states in Mexico may have different disease environments which have persisted through time. Then, for example, households in the 1920s may have migrated to escape from states with poor health conditions, and households today may continue to do the same. If this were true, we would find households in high migration states having worse health outcomes, not as a result of migration, but as a consequence of the persistent poor health conditions in those states. We examine this possibility in Table 3 by testing for independence between the infant mortality rates in 1930 taken from INEGI (2001), the earliest available at the state level, and the 1924 state level migration rates. The Spearman rank correlation coefficient of 0.23 is insignificantly different from zero, so we cannot reject the null of independence. That is, there is no significant relationship between historic infant mortality and historic migration. Nevertheless, we will include the 1930 state infant mortality as an additional control in our analysis.

A second potential threat is that in addition to spurring migration, the pattern and timing of the historical development of the railroads led to more economic development and, in particular, was accompanied by greater development of health infrastructure. As such, the historic migration rate in a state could be positively correlated with the current level of health infrastructure in that state. Table 3 examines the relationship between the 1924 migration rate and four measures of statelevel health care provision in 1996 taken from Secretaría de Salud (1997): doctors, hospital beds, nurses, and hospitals per 100,000 of population. High migration states have significantly more hospital beds per capita, but no more doctors, nurses, or hospital buildings. As a final check on overall economic development, we see a marginally significant positive correlation between 
historic migration rates and the 1997 state GDP per capita. ${ }^{9}$ Migration itself may have resulted in greater development, and so by controlling for these variables, we may be removing some of the effects of migration. Therefore we present results both with and without these controls when we examine the impact of migration on the principal health outcomes.

Column 3 of Table 2 shows that after adding these state-level controls, the 1924 state level migration rate still remains a strong instrument, while none of the state controls are individually significant. This provides us with some confidence in the validity of our instrument.

\subsection{Estimation Methods}

Standard two-stage least squares (2SLS) estimation can then be used to estimate the impact of migration on birthweight using the historic migration rate as an instrument. However infant mortality is a binary outcome, which raises additional estimation choices. Our baseline approach is to use maximum-likelihood estimation of Amemiya's generalized least squares estimator (see Newey, 1987) ${ }^{10}$, which can then be compared to the results obtained under standard probit estimation when we don't use an instrument. This reduces to a bivariate probit model when our measure of migration is the binary indicator of whether the household has a migrant member or not. We will refer to this as the IV-probit method. This method will result in predicted outcomes which lie between 0 and 1, but relies on joint normality assumptions which may not apply in practice. As an alternative, we also present results from 2SLS estimation. Angrist (1991) provides conditions under which linear instrumental variables estimation will consistently estimate average treatment effects in the case of binary endogenous variable. While these conditions are unlikely to hold exactly, Angrist uses Monte Carlo evidence to argue that they may hold approximately, and that the 2SLS technique can perform well in practice.

\footnotetext{
${ }^{9}$ State GDP per capita are obtained from the INEGI website, www.inegi.gob.mx, Sistema de Cuentas Nacionales de Mexico, accessed November 9, 2004.

${ }^{10}$ This is estimated using STATA's divprobit add-in package.
} 


\section{The Effect of Migration on Fertility}

One possible channel through which migration may affect observed child health outcomes is through fertility. Migration may alter the fertility decision through a number of avenues, such as changes in household income and the opportunity cost of time and changes in knowledge about contraceptive practices. Since births that occur at very short intervals experience higher risks of infant death (see e.g. Bongaarts, 1987), the decision of whether and when to have a child may impact on child health outcomes, irrespective of any other effects of migration on health. We therefore first use the full sample of all women aged 15-54 in our sample to assess whether any differences in child health between migrant and non-migrant families are in part due to differences in fertility.

Our measures of child health are only for households that have had a child since 1 January 1994. The first four columns of Table 4 examine whether women aged 15-54 in migrant households are any more or less likely to have had a child in this period. Columns 1 and 2 use a probit specification, while Columns 3 and 4 use regression. The probit, OLS and instrumental variables results all show a small and insignificant effect of being in a migrant household on the likelihood that a woman gave birth after the start of January 1994. Columns 5 and 6 then investigate the impact of migration on the number of children ever born to women aged 15-54 as of the survey date. The OLS results show a significant positive effect of being in a migrant household. However, after instrumenting, we find this effect to be insignificant. We therefore conclude that household migration status does not affect either the likelihood a women had a child since 1 January 1994, or total fertility. For the remainder of our analysis we therefore consider health outcomes of children conditional on the children being born.

\section{Does Migration Affect Child Health?}

\subsection{The Impact of Migration on Infant Mortality}

Table 5 examines the impact of migration on infant mortality, an extreme measure of child health outcomes. Columns 1-5 consider the effect of having at least one household member who is a migrant, while Columns 6-10 use the proportion of adults in the household with U.S. migration experience. When migration is treated as exogenous we find a small, negative, and insignificant effect of migration on infant mortality. However, once we instrument for migration status, we 
find a strongly significant negative effect of migration. Children born in households with a migrant member are estimated to be 3 percent (IVprobit) to 4.5 percent (2SLS) less likely to die in their first year than children born in households without a migrant member. Controlling for state-level health infrastructure, state historic infant mortality rates, and state GDP per capita reduces the estimated effect slightly to 3.7 percent. Likewise children in households with a higher migration prevalence are found to be statistically less likely to die as infants. A one standard deviation increase in household migration prevalence is estimated to result in a 1.8 percent lower infant mortality rate, which is approximately three times the size of the reduction associated with a one standard deviation increase in the schooling of the mother.

\subsection{Impact on Birthweight}

Birthweight is an important early indicator of child health. Infant mortality risk declines steeply with birthweight (Wolpin, 1997) and it is claimed that low birthweight can result in cognitive and neurological impairment that limits the returns to human capital investment later in life. Using data on twins, Behrman and Rosenzweig (2003) find significant positive effects of higher birthweight on schooling attainment, adult height, and labor-market payoffs. Any impact of migration on birthweight is therefore likely to have important short- and long-term effects.

Table 6 estimates the effect of migration status on birthweight in Columns 1 to 7 , and on the probability of being underweight (less than 2.5 Kilograms). The OLS results in Column 1 show a significant but small (69 gram) increase in birthweight being associated with having a migrant in the household. As discussed in Section 2, birthweight is only reported for 73 percent of the babies born after January 1, 1994, with non-reporting more prevalent among mothers with lower schooling and slightly more prevalent in non-migrant households. We use maximum-likelihood estimation of Heckman's (1979) sample selection model to examine whether differences in reporting between migrant and non-migrant households bias our estimates. ${ }^{11}$ Column 2 reveals no significant change in the migration coefficient, suggesting that non-reporting should not bias our results.

\footnotetext{
${ }^{11}$ We do not have variables which can be plausibly assumed to impact on the likelihood of non-reporting of birthweight but not on birthweight itself, so the selection correction relies on the standard functional form assumptions here.
} 
Columns 3 and 4 of Table 6 show a more sizeable impact of migration on birthweights after instrumentation. Being in a household with at least one migrant is estimated to raise birthweight by 364 grams, or 0.64 of a standard deviation, and 335 grams once state level controls are included. Birthweight is likely to be better measured for children delivered by doctors, and so in Column 5 we show the results just for this group of children, obtaining a very similar estimate of the increase in birthweight from migration as for the full sample. Column 6 shows a one standard deviation increase in household migration prevalence raises birthweight by 140 grams, or 0.25 standard deviations. This effect is five times as large as that associated with a one standard deviation increase in mother's schooling. Columns 6 and 7 provide similar results in terms of the impact of migration on the probability of being born underweight. Migration lowers this probability, with a stronger effect found after instrumentation.

Both the infant mortality and birthweight results show stronger improvements in child health from migration after instrumentation. Failure to consider the selectivity of migration therefore understates the impact of migration. This suggests that, in the absence of migration, children in what are currently migrant households would have poorer health status than children in observationally similar non-migrant households. From this we infer that on net, Mexican migrants to the U.S. are negatively selected in terms of the health status of their children.

\subsection{Impact on Health Inputs and Behaviors}

The ENADID also provides results on several health inputs, both during the time of birth and during infancy. Table 7 examines the impact of migration on whether a child was delivered by a doctor, whether they were breastfed at all, whether they visited a doctor at least once in the first year of life, and whether they received vaccinations for tuberculosis, DPT, polio and measles. After instrumenting, we find children in migrant households to be significantly more likely to be delivered by a doctor, but less likely to be breastfed, vaccinated, or visit a doctor in the first year of their life. Although migration appears to result in lower infant mortality and higher birthweights and better care at the time of delivery, it therefore appears that children of migrants receive less preventative health care in their infancy. One possible reason for this may be a higher opportunity cost of time for migrant parents, and periods where one or both parents are absent from the children, making it more difficult to breastfeed and take the child to health 
clinics. ${ }^{12}$ Nevertheless, the last two columns of Table 7 show that migrant children are slightly less likely than non-migrant children to die between the ages of one and four, conditional on surviving to at least age one, so that the positive effects of migration for health outweigh any negatives for this group.

\section{How does migration affect child health outcomes?}

The Grossman (1972) model of a health production function provides a theoretical framework which can be used to delineate the variety of mechanisms through which migration may be observed to impact on child health outcomes. ${ }^{13}$ The health status $H_{i}$ of child $i$ at a particular point in time can be written as:

$$
H_{i}=h\left(M_{i}, T_{i}, K_{i}, B_{i}, \varepsilon_{i}\right)
$$

where $M_{i}$ are the medical and nutritional inputs into the health of child $i$, such as prenatal and post-natal care, maternal and postnatal nutrition, and disease environment; $T_{i}$ are the time inputs of the parent; $K_{i}$ is parental health knowledge; $B_{i}$ are biological endowments such as genetic factors; and $\varepsilon_{i}$ are random health shocks. In Grossman's original model health is both an investment and a consumption good, entering the utility function directly. Parents will then maximize utility by choosing health inputs such that the present value of gross investment in health equals the marginal benefits. As discussed in Section 3, the migration decision of the household may be correlated with both its genetic health status, $B$, and with any random health shocks such as disease outbreaks, $\varepsilon$, and so instrumental variables are used for estimation.

The most obvious channel through which migration may affect child health is through an increase in household income and wealth. Papers which attempt to identify the causal impact of income on health have found evidence of a positive relationship at both the macro (Pritchett and Summers, 1996) and micro (Strauss and Thomas, 1998) levels. As Wolpin (1997) notes, financial resources are not themselves direct inputs into health production, but rather determinants of the behaviors leading to the choices of $M_{i}$ and $T_{i}$. Higher income will allow

\footnotetext{
${ }^{12}$ Discussants at the Economia session in Costa Rica also noted that using baby formula in place of breast-feeding is seen to be advantageous in some Latin American countries in light of poor nutritional status of the mothers. However, breast-feeding is associated with a number of positive health outcomes and is recommended by the World Health Organization (see González-Cosslo et al. 2003).

${ }^{13}$ See also the detailed discussion of the health production approach in Wolpin (1997).
} 
households to purchase more medical and nutritional inputs since health is a normal good. Secondly, the income from migration may relax liquidity constraints that prevent parents from investing in child health in the current period in order to reap the returns in the future. Moreover, the migration experience developed by parents will make it easier for their children to migrate; raising the expected adult wages of children and hence returns to investment in their health.

\subsection{Migration and Health Knowledge}

Migration may also impact on health outcomes through non-monetary channels. One such channel is the transfer of health knowledge information. Grossman (1972) allows for education to change the efficiency of the health production process, allowing for better health production from a given input set. Glewwe (1999) studies the mechanisms through which mother's education raises child health in Morocco and concludes that mother's health knowledge rather than their level of schooling per se is the crucial skill for improving child health. Migrants may gain information about basic health practices while abroad and share this with family members. Such information may include better understanding of contraceptive practices, the importance of sanitation, and knowledge about diet, exercise and other lifestyle behaviors. Menjívar (2002) provides evidence that social networks among Guatemalan immigrants in the U.S. engage in regular transmission of medical knowledge, helping one another with information about treatments and health advice.

As discussed in the Appendix, we measure health knowledge by the first principal component of a set of questions asking mothers whether they can name on their own or with help ten different contraceptive methods. This provides a measure of health knowledge which clearly represents fertility knowledge, and may be broadly associated with more general health knowledge on the part of the mother. For example, using data from the Mexican Health and Migration Survey (HMS) taken in eleven communities in the state of San Luis Potosi, we find a strong and significant correlation between our measure of health knowledge and whether the mother has a good explanation for the causes of diarrhea. ${ }^{14}$ Table 8 examines the impact of migration on the health knowledge of mothers. Columns 1 and 2 show that mothers in migrant households are found to have more health knowledge than mothers in non-migrant households. After

\footnotetext{
${ }^{14}$ See www.mexmah.com for further description of this survey.
} 
instrumenting, we find a strong effect of migration: being in a migrant household is estimated to increase health knowledge by 0.65 standard deviations.

The remainder of Table 8 explores further this increase in health knowledge. If health knowledge is gained directly by the migrant member, then one should expect to see a much larger increase in maternal health knowledge if the mother herself has migrated compared to when her husband or other family member migrates. The problem in attempting to examine this is that households choose whether to send the future mother, father, or both, and households which choose to send a mother may differ along a number of dimensions, including health knowledge, to those which choose to send a father. We do not have a suitable instrument for determining which household member migrates, and so present two sets of results. Columns 3 and 4 compare households in which the mother is a migrant to households with no migrant members, while Columns 5 and 6 compare households in which the father is a migrant to households with no migrant members. We do indeed find that the increase in maternal knowledge associated with the mother migrating is larger than with the father migrating. However, we can not rule out that this result may just reflect a selection effect, whereby households in historically high migration areas will only send a mother rather than a father if the mother has a high level of health knowledge.

Health knowledge may also be transmitted from one migrant family to another, and from migrant households to non-migrant households in the same community. These spillovers can act to reinforce knowledge gained from migrant members, and may contribute to the large gains in health knowledge we observe. Columns 7 and 8 of Table 8 examine whether mothers in nonmigrant households living in communities with a large number of migrants have more health knowledge than mothers in non-migrant households living in communities with fewer migrants in order to examine the evidence for health knowledge spillovers. We restrict our sample to communities where at least 50 households were surveyed for this analysis. After instrumenting we do find significantly higher health knowledge among non-migrant households in higher migration communities. The 2SLS coefficient finds that a one standard deviation increase in community migration prevalence results in a 0.11 standard deviation increase in health knowledge of non-migrant mothers. Since health knowledge is transmitted to non-migrant households, it appears likely that some of the large impact of migration on health knowledge in 
migrant households may also result from spillovers from other migrant families.

\subsection{Wealth and Knowledge Effects}

The ENADID does not contain information on time allocation, nutrition, or many other inputs into the health production function and household income is only partially measured. We therefore examine the joint impact of migration on health outcomes through wealth, proxied by household infrastructure, and through the health knowledge gains determined above. The ENADID contains information on household infrastructure, including whether they have a dirt, cement or wood floor, access to running water, their type of sanitation service, how their dirty water is disposed of, and whether they have electricity. We take the first principal component to form an infrastructure index of these components. Filmer and Pritchett (2001) show that such an index can provide reasonable estimates of wealth level effects in situations where wealth data are not directly available. Moreover, better infrastructure may also act as a direct input in the health production function. Column 1 of Table 9 shows that migration results in higher scores of this infrastructure index, reflecting the direct wealth effect of migration. Column 2 repeats the health knowledge regression of Table 8 for the sample of all mothers, not just spouses and household heads and again finds an increase in health knowledge arising from migration.

Migration is therefore seen to result in more wealth and more health knowledge. In order to approximate how much of the reduction in infant mortality and increase in birthweight from migration can be attributed to these channels, we therefore reestimate the health outcome regressions, replacing migration with health knowledge and the wealth infrastructure index. We do this for the sample of non-migrant households to predict the change in health outcome associated with the changes in health knowledge and infrastructure due to migration. Columns 3 and 4 of Table 9 present the reduced form estimates. We find an increase in the health knowledge index and in the infrastructure index are both significantly associated with higher birthweight and marginally significantly associated with lower infant mortality.

The two-stage least squares estimates of the increases in health knowledge and infrastructure due to migration can then be combined with the estimated change in health status associated with changes in health knowledge and infrastructure. This results in an estimated 0.5 percent fall in 
infant mortality and 66 gram increase in birthweight arising from the impact of migration through the mechanisms of health knowledge and wealth infrastructure. These channels thereby explain approximately one-sixth of the estimated overall migration impacts on these child health outcomes. $^{15}$ Given the measurement problems with income and the lack of data on time allocation and other inputs, we are unable to provide a complete decomposition of the channels through which migration matters for child health, but have demonstrated the potential for health knowledge gains to play an important role.

\section{Conclusions}

This paper has found that migration from Mexico to the U.S. improves child health outcomes in Mexico, resulting in lower rates of infant mortality and higher birthweights. We find that failure to control for the selectivity of migration understates the health effects, suggesting that migrants are negatively selected from the overall rural distribution in terms of the health of their children. We then break down some of the channels through which migration affects child health status, and show that in addition to health improvements which arise from income or wealth effects, having a migrant member is associated with sizeable increases in the health knowledge on the part of mothers. Nevertheless, despite these improvements in immediate health status, we also find that children of migrants are less likely to be breastfed, fully vaccinated, or to visit a doctor in the first year of their life. Although child mortality between age one and four is not negatively impacted by migration on net, there may be longer-term negative impacts on health outcomes arising from absent parents and the results suggest a need for future research into understanding the causes of lower preventative healthcare among migrants in order to develop appropriate policy responses.

This research contributes more generally toward a broader view of the benefits and costs of migration for Mexico than that offered by the amount of remittances and number of migrants which frame much of the policy debate. Mexican immigration continues to be a key political issue on both sides of the border, and various proposals have been made for immigration reform. More detailed analysis of the effects of migration on Mexican communities holds the potential

\footnotetext{
${ }^{15}$ If one considers the standard errors associated with both the estimated impact of migration on health knowledge and infrastructure, and with the point estimates of the changes in health status associated with changes in health knowledge and infrastructure, then these channels can explain up to 80 percent of the overall migration impact.
} 
for informing this policy debate and for understanding the likely consequences of any policy changes on Mexico's long-term development. The research provided in this paper enables clear identification of one such effect, showing migration has the potential to result in sizeable effects on child health.

\section{Appendix: Constructing an index of health knowledge}

The ENADID contains a set of questions to all women aged 15 to 54 about their knowledge of ten different contraceptive methods: the birth control pill, condoms, diaphragms or sponges, intrauterine devices (IUDs), injections, Norplant implants, tubal occlusion, vasectomy, natural family planning such as the Rhythm Method, and Withdrawal. The method of principal components is used to reduce these ten yes/no answers into a single index. The first principal component is the linear combination of the set of variables whose sample variance is greatest among all such linear combinations, subject to a normalization restriction. ${ }^{16}$ The underlying assumption is that general health knowledge explains the maximum variation in knowledge over these different methods. Methods in which knowledge varies most across households are given more weight in constructing the index. The first principal component is found to explain 39 percent of the overall variance in answers to these ten questions. Table A1 gives the scoring factors and mean and standard deviation for each method. Knowledge of the birth control pill, IUDs and contraceptive injections results are the methods which contribute most to the index.

\footnotetext{
${ }^{16}$ Everitt and Dunn (2001) provide a good introduction to this methodology.
} 


\section{References}

Angrist, Joshua D. 1991. "Instrumental Variables Estimation of Average Treatment Effects in Econometrics and Epidemiology." National Bureau of Economic Research Working Paper No. 115.

Barham, Bradford and Stephen Boucher. 1998. "Migration, remittances and inequality: estimating the net effect of migration on income distribution", Journal of Development Economics 55: 307-31.

Behrman, Jere R. and Mark R. Rosenzweig. 2003. "Returns to Birthweight", mimeo. University of Pennsylvania.

Bongaarts, John. 1987. “Does Family Planning Reduce Infant Mortality Rates?”, Population and Development Review 13(2): 323-34.

Borjas, George J. 1999. Heaven's Door: Immigration policy and the American economy, Princeton University Press: Princeton, NJ.

Borjas, George J. 1987. "Self-selection and the Earnings of Immigrants", American Economic Review 77(4): 531-53.

Durand, Jorge; Emilio A. Parrado and Douglas S. Massey. 1996. "Migradollars and Development: A Reconsideration of the Mexican Case." International Migration Review Summer 30(2): 423-444.

Espinosa, Kristin and Douglas Massey. 1997. "Undocumented Migration and the Quantity and Quality of Social Capital", Soziale Welt 12: 141-62.

Escobar Latapí, Agustín, Philip Martin, Paul S. Davies, Gustavo López Castro and Katharine Donato. 1998. "Factors that Influence Migration”, pp. 163-250 in Migration between Mexico and the United States: Binational Study Volume 1. U.S. Commission on Immigration Reform: Washington D.C.

Everitt, Brian S. and Graham Dunn. 2001. Applied Multivariate Data Analysis, Second Edition. Oxford University Press: Cambridge, MA.

Filmer, Deon and Lant Pritchett. 2001. "Estimating Wealth Effects Without Expenditure Data or Tears: An Application to Educational Enrollments in States of India”, Demography 38(1): 115-132.

Foerster, Robert F. 1925. The Racial Problems Involved in Immigration from Latin America 
and the West Indies to the United States. Washington, DC: The United States Department of Labor.

Frank, Reanne and Robert A. Hummer. 2002. "The Other Side of the Paradox: The Risk of Low Birth Weight among Infants of Migrant and Nonmigrant Households within Mexico", International Migration Review 36(3): 746-65.

Glewwe, Paul. 1999. "Why Does Mother's Schooling Raise Child Health in Developing Countries? Evidence from Morocco." The Journal of Human Resources Winter 34(1): 124-159.

González-Cosslo, Teresa et al. (2003) "Breast-feeding practices in Mexico: Results from the Second Nacional Nutrition Survey 1999”, Salud Pública de México 45(4): 477-489.

Grossman, Michael. 1972. "On the Concept of Health Capital and the Demand for Health." Journal of Political Economy March-April 80(2): 223-255.

Hanson, Gordon H. and Christopher Woodruff. 2003. "Emigration and Educational Attainment in Mexico", mimeo. University of California, San Diego.

Heckman, James J. 1979. "Sample Selection Bias as a Specification Error”, Econometrica 47(1): 153-161.

Iliana Chávez, M. 2003. "Las remesas de los migrantes superarán la inversion extranjera" (Migrant's remittances will surpass foreign investment), pages 1A and 4A in El Herald de Mexico, 9 October 2003.

Institute of Medicine. 1998. From Generation To Generation: The Health And Well-Being Of Children In Immigrant Families. National Research Council, Washington DC.

Instituto Nacional de Estadística Geografía e Informática (INEGI). (2001) Estadísticas Históricas de Mexico 2000 CD-ROM. INEGI: Aguascalientes, Mexico.

Instituto Nacional de Estadística Geografía e Informática (INEGI). (1999). ENADID: Encuesta Nacional de la Dinámica Demográfica 1997. INEGI: Aguascalientes, Mexico.

Johnson, Scott and Joseph Contreras. 2004. "The Migration Economy," Newsweek, January 19: 36.

Kanaiaupuni, Shawn and Katharine M. Donato. 1999. "Migradollars and Mortality: The Effects of Migration on Infant Survival in Mexico.” Demography August 36(3): 339-353.

Massey, Douglas S.; Jorge Durand and Nolan J. Malone. 2002. Beyond Smoke and Mirrors: Mexican Immigration in an Era of Economic Integration. New York: Russell Sage 
Foundation.

Massey, Douglas S.; Luin Goldring; and Jorge Durand. 1994. "Continuities in Transnational Migration: An Analysis of Nineteen Mexican Communities." American Journal of Sociology May 99(6): 1492-1533.

McKenzie, David and Hillel Rapoport. 2004. "Network Effects and the Dynamics of Migration and Inequality: Theory and Evidence from Mexico.” BREAD Working Paper No. 063.

Menjívar, Cecilia. 2002. “The Ties that Heal: Guatemalan Immigrant Women's Networks and Medical Treatment”, International Migration Review 36(2): 437-66.

Munshi, Kaivan. 2003. "Networks in the Modern Economy: Mexican Migrants in the U.S. Labor Market." The Quarterly Journal of Economics May 118(2): 549-599.

Newey, Whitney K. 1987. "Efficient Estimation of Limited Dependent Variable Models with Endogenous Explanatory Variables." The Journal of Econometrics November 36(3): 231-250.

Pan American Health Organization (PAHO). 1998. Health in the Americas 1998 Edition, World Health Organization: Washington D.C.

Pritchett, Lant and Lawrence H. Summers. 1996. "Wealthier is Healthier." The Journal of Human Resources Autumn 31(4): 841-68.

Secretaría de Salud (1997) "Información básica sobre recursos y servicios del Sistema Nacional de Salud", Salud Pública de México 39(6): 580-90.

Strauss, John and Duncan Thomas. 1998. "Health, Nutrition, and Economic Development." Journal of Economic Literature June 36(2): 766-817.

UNICEF. 1997. “The Progress of Nations 1997”, available online at www.unicef.org/pon97 accessed September 16, 2004.

Winters, Paul; Alain de Janvry and Elisabeth Sadoulet. 2001. "Family and Community Networks in Mexico-U.S. Migration." The Journal of Human Resources Winter 36(1): 159-184.

Wolpin, Kenneth I. 1997. "Determinants and Consequences of the Mortality and Health of Infants and Children”, pp. 483-557 in M.R. Rosenzweig and O. Stark (eds.) Handbook of Population and Family Economics Volume 1A, Elsevier: New York.

Woodruff, Christopher and Rene Zenteno. 2001. "Remittances and Microenterprises in Mexico.” Working Paper, UCSD and ITESM-Guadelejara, December. 
Figure 1: Map of 1924 state migration rates

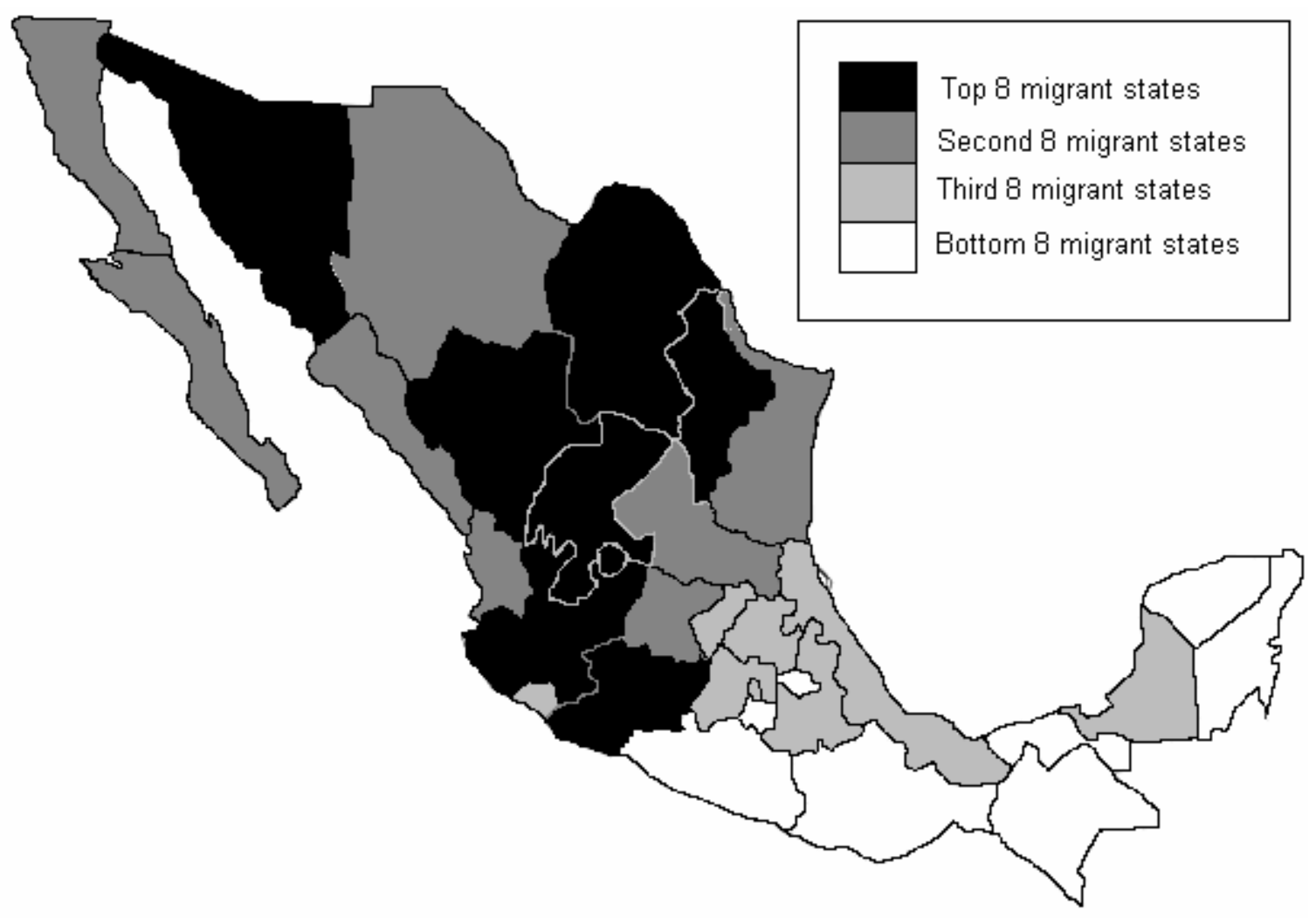


Table 1: Summary Statistics and Tests of Differences in Means

For sample of households with a child born since 1 January 1994

\begin{tabular}{|c|c|c|c|c|c|c|c|}
\hline & \multirow[b]{2}{*}{ \#Obs. } & \multicolumn{2}{|c|}{ All households } & \multirow{2}{*}{$\begin{array}{c}\text { Migrant HHs } \\
\text { Mean }\end{array}$} & \multicolumn{2}{|c|}{ Non-migrant HHS T-statistic } & \multirow[t]{2}{*}{ p-value } \\
\hline & & Mean & S.D. & & Mean & & \\
\hline \multicolumn{8}{|l|}{ Household Level Observations } \\
\hline Household Migration Prevalence 1994 & 12396 & 0.094 & 0.214 & 0.488 & 0.000 & & \\
\hline Proportion of $\mathrm{HHs}$ with at least one migrant & 12396 & 0.193 & 0.395 & 1 & 0 & & \\
\hline State migration rate in 1924 & 12396 & 0.007 & 0.009 & 0.012 & 0.006 & -30.92 & 0.000 \\
\hline State migration rate in $1955-59$ & 12396 & 0.015 & 0.016 & 0.025 & 0.013 & -34.17 & 0.000 \\
\hline Income per capita & 12396 & 422.1 & 595.5 & 404.4 & 426.3 & 1.61 & 0.107 \\
\hline Infrastructure Index & 12088 & 0.000 & 2.046 & 0.299 & -0.072 & -7.91 & 0.000 \\
\hline Household Size & 12396 & 5.594 & 2.422 & 5.700 & 5.568 & -2.39 & 0.017 \\
\hline Number of recent mothers aged $15-54$ & 12396 & 1.034 & 0.196 & 1.036 & 1.033 & -0.63 & 0.526 \\
\hline Number of children born since 1 Jan 1994 & 12396 & 1.344 & 0.595 & 1.358 & 1.340 & -1.30 & 0.195 \\
\hline \multicolumn{8}{|l|}{ Mother Level Observations } \\
\hline Mother's Age & 12767 & 27.5 & 6.6 & 28.4 & 27.3 & -7.52 & 0.000 \\
\hline Mother's Years of Schooling & 12767 & 6.68 & 3.46 & 6.65 & 6.69 & 0.43 & 0.670 \\
\hline Mothers Health Knowledge Index & 12720 & 0.000 & 1.978 & 0.298 & -0.072 & -8.35 & 0.000 \\
\hline \multicolumn{8}{|l|}{ Child Level Observations } \\
\hline Infant mortality rate per 1000 & 16593 & 23.7 & 152.3 & 21.0 & 24.4 & 1.16 & 0.247 \\
\hline Birth weight (Kgs) & 12117 & 3.251 & 0.564 & 3.310 & 3.235 & -5.87 & 0.000 \\
\hline Proportion underweight & 12117 & 0.075 & 0.264 & 0.058 & 0.080 & 3.71 & 0.000 \\
\hline Proportion delivered by Doctor & 14083 & 0.768 & 0.422 & 0.851 & 0.749 & -11.65 & 0.000 \\
\hline Proportion breastfed & 14571 & 0.905 & 0.293 & 0.891 & 0.908 & 2.76 & 0.006 \\
\hline Proportion visiting Doctor in first year of life & 14079 & 0.795 & 0.403 & 0.782 & 0.798 & 1.93 & 0.054 \\
\hline Proportion Receiving all vaccines & 13989 & 0.733 & 0.442 & 0.738 & 0.732 & -0.57 & 0.568 \\
\hline
\end{tabular}

Notes:

T-test tests for difference in means between migrant and non-migrant households

All vaccines includes vaccines for tuberculosis, polio, DPT and measles.

Migrant households are defined as households with at least one migrant to the U.S. prior to the start of 1994.

Recent mothers are defined as mothers of children born since 1 January 1994. 
Table 2: First Stage Results

\begin{tabular}{|c|c|c|c|c|}
\hline & & $\begin{array}{l}\text { isehold } h \\
\text { rant mem }\end{array}$ & & $\begin{array}{l}\text { Household } \\
\text { migration }\end{array}$ \\
\hline & (1) & $\begin{array}{l}(2) \\
\text { (2) }\end{array}$ & $\begin{array}{l}\text { (3) } \\
\text { (3) }\end{array}$ & (4) \\
\hline 1924 Migration Rate & 11.240 & 12.541 & 12.789 & 6.405 \\
\hline & $(5.84)^{\star *}$ & $(6.09)^{* *}$ & $(5.70)^{\star *}$ & $(5.69)^{\star *}$ \\
\hline Age of Mother & 0.013 & 0.012 & 0.011 & 0.015 \\
\hline & $(3.92)^{* *}$ & $(3.40)^{* *}$ & $(3.15)^{\star *}$ & $(5.00)^{\star *}$ \\
\hline Age of Mother Squared & -0.000 & -0.000 & -0.000 & -0.000 \\
\hline & $(2.98)^{\star \star}$ & $(2.55)^{*}$ & $(2.42)^{\star}$ & $(4.47)^{\star *}$ \\
\hline Mother's Years of Schooling & -0.000 & -0.001 & -0.000 & -0.002 \\
\hline & $(0.14)$ & $(0.40)$ & $(0.29)$ & $(1.48)$ \\
\hline Household Size & 0.005 & 0.005 & 0.004 & -0.005 \\
\hline & $(2.41)^{*}$ & $(2.38)^{*}$ & $(2.20)^{*}$ & $(4.41)^{* *}$ \\
\hline State-level controls & & & & \\
\hline Infant mortality rate in 1930 & & & $\begin{array}{l}0.001 \\
(1.23)\end{array}$ & \\
\hline Doctors per 100,000 population & & & $\begin{array}{l}0.000 \\
(0.02)\end{array}$ & \\
\hline Hospital beds per 100,000 population & & & $\begin{array}{r}-0.000 \\
(0.24)\end{array}$ & \\
\hline Nurses per 100,000 population & & & $\begin{array}{l}0.001 \\
(0.37)\end{array}$ & \\
\hline Hospitals per 100,000 population & & & $\begin{array}{l}-0.063 \\
(1.51)\end{array}$ & \\
\hline State GDP per capita 1997 & & & $\begin{array}{r}-0.008 \\
(1.65)\end{array}$ & \\
\hline Constant & & $\begin{array}{l}-0.117 \\
(2.29)^{*}\end{array}$ & $\begin{array}{l}-0.119 \\
(1.47)\end{array}$ & $\begin{array}{c}-0.140 \\
(3.90)^{* *}\end{array}$ \\
\hline Observations & 16593 & 16593 & 16593 & 16593 \\
\hline R-squared & & 0.08 & 0.09 & 0.08 \\
\hline F-statistic on 1924 migration rate & 34.1 & 37.1 & 32.5 & 32.4 \\
\hline
\end{tabular}

Notes:

Robust t-statistics in parentheses clustered at the state level

State-level health infrastructure data are for 1996.

Coefficients for the probit are marginal effects.

${ }^{*}$ significant at $5 \% ;{ }^{* *}$ significant at $1 \%$ 
Table 3: Correlations between Historic Migration Rates and Other State Level Variables

\begin{tabular}{lcc}
\hline State-level variable & $\begin{array}{c}\text { Rank-order correlation } \\
\text { with 1924 state migration }\end{array}$ & $\begin{array}{c}\text { p-value for test } \\
\text { of independence }\end{array}$ \\
\hline Infant mortality in 1930 & 0.2268 & 0.212 \\
doctors per 100,000 in 1996 & 0.1381 & 0.451 \\
beds per 100,000 in 1996 & 0.4003 & 0.023 \\
nurses per 100,000 in 1996 & 0.2584 & 0.153 \\
hospitals per 100,000 in 1996 & -0.0457 & 0.804 \\
1997 state GDP per capita & 0.3108 & 0.083 \\
\hline
\end{tabular}


Table 4: Does migration affect fertility?

\begin{tabular}{|c|c|c|c|c|c|c|c|}
\hline & \multicolumn{5}{|c|}{ Mother had a child after 1 January 1994} & \multicolumn{2}{|c|}{ Total \# children ever born } \\
\hline & (1) & (2) & $(3)$ & $(4)$ & $(5)$ & $(6)$ & (7) \\
\hline & Probit & IVProbit & OLS & 2SLS & 2SLS & OLS & 2SLS \\
\hline Migrant household & $\begin{array}{l}-0.009 \\
(1.45)\end{array}$ & $\begin{array}{l}0.008 \\
(0.39)\end{array}$ & $\begin{array}{l}-0.007 \\
(1.09)\end{array}$ & $\begin{array}{l}0.009 \\
(0.26)\end{array}$ & $\begin{array}{l}0.031 \\
(0.81)\end{array}$ & $\begin{array}{c}0.140 \\
(3.50)^{\star *}\end{array}$ & $\begin{array}{l}0.375 \\
(1.43)\end{array}$ \\
\hline Mother's age & $\begin{array}{c}0.131 \\
(50.69)^{* *}\end{array}$ & $\begin{array}{c}0.131 \\
(71.01)^{* *}\end{array}$ & $\begin{array}{c}0.081 \\
(31.76)^{* *}\end{array}$ & $\begin{array}{c}0.081 \\
(31.70)^{\star *}\end{array}$ & $\begin{array}{c}0.081 \\
(31.74)^{* *}\end{array}$ & $\begin{array}{c}0.249 \\
(23.44)^{\star *}\end{array}$ & $\begin{array}{c}0.250 \\
(24.32)^{\star *}\end{array}$ \\
\hline Mother's age squared & $\begin{array}{c}-0.002 \\
(48.56)^{* *}\end{array}$ & $\begin{array}{c}-0.002 \\
(71.58)^{* *}\end{array}$ & $\begin{array}{c}-0.001 \\
(38.26)^{* *}\end{array}$ & $\begin{array}{c}-0.001 \\
(38.15)^{\star *}\end{array}$ & $\begin{array}{c}-0.001 \\
(38.23)^{* *}\end{array}$ & $\begin{array}{l}-0.001 \\
(7.57)^{\star *}\end{array}$ & $\begin{array}{c}-0.001 \\
(7.84)^{\star *}\end{array}$ \\
\hline Mother's years of schooling & $\begin{array}{c}-0.014 \\
(19.72)^{\star *}\end{array}$ & $\begin{array}{c}-0.014 \\
(24.32)^{\star *}\end{array}$ & $\begin{array}{c}-0.013 \\
(16.04)^{\star *}\end{array}$ & $\begin{array}{c}-0.013 \\
(15.83)^{* *}\end{array}$ & $\begin{array}{c}-0.013 \\
(14.57)^{\star *}\end{array}$ & $\begin{array}{c}-0.174 \\
(41.07)^{\star *}\end{array}$ & $\begin{array}{c}-0.173 \\
(40.91)^{* *}\end{array}$ \\
\hline state-level controls & no & no & no & no & yes & yes & yes \\
\hline $\begin{array}{l}\text { Observations } \\
\text { R-squared }\end{array}$ & 42527 & 42527 & $\begin{array}{c}42527 \\
0.13\end{array}$ & 42527 & 42527 & $\begin{array}{c}40372 \\
0.55\end{array}$ & 40372 \\
\hline
\end{tabular}

Notes:

Robust t-statistics in parentheses clustered at the state level Coefficients for the probit are marginal effects giving the discrete change in the probability of a child being born for being in a migrant household, and the change in the probability for infinitesimal changes in the other variables.

1924 state migration rate is used as instrument for being in a migrant household

State level controls are 1930 infant mortality rate, health infrastructure, and 1997 GDP per capita.

* significant at $5 \%$; ${ }^{* *}$ significant at $1 \%$ 
Table 5: The Effect of Migration on Infant Mortality

Dependent variable: Child died before age one dummy variable

\begin{tabular}{|c|c|c|c|c|c|c|c|c|c|c|}
\hline & $\begin{array}{c}(1) \\
\text { Probit }\end{array}$ & $\begin{array}{c}(2) \\
\text { IVProbit }\end{array}$ & $\begin{array}{c}\text { (3) } \\
\text { OLS }\end{array}$ & $\begin{array}{c}(4) \\
2 S L S\end{array}$ & $\begin{array}{c}(5) \\
2 S L S\end{array}$ & $\begin{array}{c}(6) \\
\text { Probit }\end{array}$ & $\begin{array}{c}(7) \\
\text { IVProbit }\end{array}$ & $\begin{array}{c}\text { (8) } \\
\text { OLS }\end{array}$ & $\begin{array}{c}(9) \\
2 S L S\end{array}$ & $\begin{array}{c}(10) \\
2 S L S\end{array}$ \\
\hline Migrant household & $\begin{array}{r}-0.003 \\
(0.96)\end{array}$ & $\begin{array}{c}-0.030 \\
(3.97)^{* *}\end{array}$ & $\begin{array}{c}-0.003 \\
(1.07)\end{array}$ & $\begin{array}{c}-0.045 \\
(4.10)^{\star *}\end{array}$ & $\begin{array}{c}-0.037 \\
(3.21)^{* *}\end{array}$ & & & & & \\
\hline Mother's age & $\begin{array}{l}-0.002 \\
(1.27)\end{array}$ & $\begin{array}{r}-0.001 \\
(0.74)\end{array}$ & $\begin{array}{r}-0.002 \\
(1.12)\end{array}$ & $\begin{array}{r}-0.001 \\
(0.79)\end{array}$ & $\begin{array}{r}-0.001 \\
(0.85)\end{array}$ & $\begin{array}{r}-0.002 \\
(1.22)\end{array}$ & $\begin{array}{r}-0.000 \\
(0.15)\end{array}$ & $\begin{array}{r}-0.002 \\
(1.07)\end{array}$ & $\begin{array}{r}-0.000 \\
(0.27)\end{array}$ & $\begin{array}{r}-0.001 \\
(0.42)\end{array}$ \\
\hline Mother's age squared & $\begin{array}{l}0.000 \\
(1.24)\end{array}$ & $\begin{array}{l}0.000 \\
(0.84)\end{array}$ & $\begin{array}{l}0.000 \\
(1.12)\end{array}$ & $\begin{array}{l}0.000 \\
(0.90)\end{array}$ & $\begin{array}{l}0.000 \\
(0.93)\end{array}$ & $\begin{array}{l}0.000 \\
(1.20)\end{array}$ & $\begin{array}{l}0.000 \\
(0.27)\end{array}$ & $\begin{array}{l}0.000 \\
(1.07)\end{array}$ & $\begin{array}{l}0.000 \\
(0.40)\end{array}$ & $\begin{array}{l}0.000 \\
(0.52)\end{array}$ \\
\hline Mother's years of schooling & $\begin{array}{c}-0.002 \\
(5.22)^{\star \star}\end{array}$ & $\begin{array}{c}-0.002 \\
(5.21)^{\star \star}\end{array}$ & $\begin{array}{c}-0.002 \\
(5.04)^{\star *}\end{array}$ & $\begin{array}{c}-0.002 \\
(5.16)^{\star *}\end{array}$ & $\begin{array}{c}-0.002 \\
(5.00)^{\star *}\end{array}$ & $\begin{array}{c}-0.002 \\
(5.24)^{\star *}\end{array}$ & $\begin{array}{c}-0.002 \\
(5.49)^{\star *}\end{array}$ & $\begin{array}{c}-0.002 \\
(5.06)^{\star *}\end{array}$ & $\begin{array}{c}-0.002 \\
(5.38)^{\star *}\end{array}$ & $\begin{array}{c}-0.002 \\
(5.28)^{\star *}\end{array}$ \\
\hline Household Size & $\begin{array}{r}-0.001 \\
(1.53)\end{array}$ & $\begin{array}{l}-0.001 \\
(2.00)^{*}\end{array}$ & $\begin{array}{r}-0.001 \\
(1.58)\end{array}$ & $\begin{array}{r}-0.001 \\
(1.47)\end{array}$ & $\begin{array}{r}-0.001 \\
(1.72)\end{array}$ & $\begin{array}{r}-0.001 \\
(1.58)\end{array}$ & $\begin{array}{c}-0.002 \\
(3.32)^{\star *}\end{array}$ & $\begin{array}{r}-0.001 \\
(1.64)\end{array}$ & $\begin{array}{l}-0.002 \\
(2.20)^{*}\end{array}$ & $\begin{array}{l}-0.002 \\
(2.26)^{*}\end{array}$ \\
\hline Household Migration Prevalence & & & & & & $\begin{array}{l}-0.009 \\
(1.36)\end{array}$ & $\begin{array}{c}-0.090 \\
(3.97)^{* *}\end{array}$ & $\begin{array}{r}-0.009 \\
(1.55)\end{array}$ & $\begin{array}{c}-0.088 \\
(3.97)^{\star *}\end{array}$ & $\begin{array}{c}-0.073 \\
(3.28)^{\star *}\end{array}$ \\
\hline state controls & no & no & no & no & yes & no & no & no & no & yes \\
\hline Observations & 16593 & 16593 & 16593 & 16593 & 16593 & 16593 & 16593 & 16593 & 16593 & 16593 \\
\hline
\end{tabular}

Notes:

Robust t-statistics in parentheses clustered at the state level

Coefficients for the probit are marginal effects giving the discrete change in the probability of an infant dying

for a migrant household, and the change in the probability for infinitesimal changes in the other variables.

1924 state migration rate is used as instrument for being in a migrant household

State level controls are 1930 infant mortality rate, health infrastructure, and 1997 GDP per capita.

${ }^{*}$ significant at $5 \%$; ** significant at $1 \%$ 
Table 6: The Effect of Migration on Birthweight

\begin{tabular}{|c|c|c|c|c|c|c|c|c|c|}
\hline & \multicolumn{7}{|c|}{ Birthweight in Kilograms } & \multicolumn{2}{|c|}{ Underweight } \\
\hline & (1) & (2) & (3) & $(4)$ & (5) & (6) & (7) & (8) & (9) \\
\hline & OLS & Heckman & 2SLS & 2SLS & 2SLS & OLS & 2SLS & Probit & IVProbit \\
\hline \multirow[t]{2}{*}{ Migrant household } & 0.069 & 0.065 & 0.364 & 0.335 & 0.350 & & & -0.021 & -0.054 \\
\hline & $(4.00)^{\star *}$ & $(3.68)^{* *}$ & $(2.79)^{* *}$ & $(3.51)^{\star *}$ & $(4.11)^{\star *}$ & & & $(2.81)^{\star *}$ & $(2.59)^{* *}$ \\
\hline \multirow{2}{*}{ Mother's age } & 0.022 & 0.021 & 0.017 & 0.019 & 0.019 & 0.021 & 0.013 & -0.007 & -0.006 \\
\hline & $(2.77)^{\star *}$ & $(2.60)^{\star *}$ & $(2.11)^{*}$ & $(2.53)^{*}$ & $(2.26)^{*}$ & $(2.69)^{*}$ & $(1.58)$ & $(2.05)^{\star}$ & $(2.11)^{*}$ \\
\hline \multirow[t]{2}{*}{ Mother's age squared } & -0.000 & -0.000 & -0.000 & -0.000 & -0.000 & -0.000 & -0.000 & 0.000 & 0.000 \\
\hline & $(1.62)$ & $(1.43)$ & (1.15) & $(1.39)$ & $(1.26)$ & $(1.52)$ & $(0.62)$ & $(1.70)$ & $(1.78)$ \\
\hline \multirow[t]{2}{*}{ Mother's years of schooling } & 0.007 & 0.005 & 0.008 & 0.007 & 0.007 & 0.006 & 0.008 & -0.003 & -0.003 \\
\hline & $(4.55)^{\star *}$ & $(3.71)^{\star *}$ & $(4.59)^{\star \star}$ & $(4.59)^{\star *}$ & $(4.49)^{\star \star}$ & $(4.28)^{\star \star}$ & $(5.02)^{\star *}$ & $(4.02)^{\star *}$ & $(4.47)^{\star *}$ \\
\hline \multirow[t]{2}{*}{ Household Size } & -0.006 & -0.006 & -0.008 & -0.006 & -0.005 & -0.003 & -0.000 & 0.001 & 0.001 \\
\hline & $(2.67)^{*}$ & $(2.61)^{\star *}$ & $(3.47)^{\star *}$ & $(3.03)^{* *}$ & $(2.31)^{*}$ & $(1.41)$ & $(0.06)$ & $(0.43)$ & $(0.79)$ \\
\hline \multirow[t]{2}{*}{ Household Migration Prevalence } & & & & & & 0.143 & 0.653 & & \\
\hline & & & & & & $(4.19)^{\star *}$ & $(3.59)^{* *}$ & & \\
\hline state controls & no & no & no & yes & yes & yes & yes & yes & yes \\
\hline sub-sample of doctor-delivered & no & no & no & no & yes & no & no & no & no \\
\hline Observations & 12117 & 16593 & 12117 & 12117 & 10687 & 12117 & 12117 & 12117 & 12117 \\
\hline
\end{tabular}

Notes:

Robust t-statistics in parentheses clustered at the state level

Coefficients for the probit are marginal effects giving the discrete change in the probability of being underweight

for a migrant household, and the change in the probability for infinitesimal changes in the other variables.

1924 state migration rate is used as instrument for being in a migrant household

Column (2) corrects for selectivity due to missing observations on birthweight

Column (5) is only for the sub-sample of babies delivered by a doctor

State level controls are 1930 infant mortality rate, health infrastructure, and 1997 GDP per capita.

* significant at $5 \% ;{ }^{* *}$ significant at $1 \%$ 
Table 7: The Impact of Migration on Health Inputs

\begin{tabular}{|c|c|c|c|c|c|c|c|c|c|c|}
\hline & \multicolumn{2}{|c|}{$\begin{array}{l}\text { Child was delivered } \\
\text { by a Doctor }\end{array}$} & \multicolumn{2}{|c|}{$\begin{array}{l}\text { Child was } \\
\text { breastfed }\end{array}$} & \multicolumn{2}{|c|}{$\begin{array}{l}\text { Visited Doctor in } \\
\text { child's first year }\end{array}$} & \multicolumn{2}{|c|}{$\begin{array}{l}\text { Child received } \\
\text { all vaccines }\end{array}$} & \multicolumn{2}{|c|}{$\begin{array}{l}\text { Probability of dying } \\
\text { aged one to four }\end{array}$} \\
\hline & $\begin{array}{c}(1) \\
\text { Probit }\end{array}$ & $\begin{array}{c}(2) \\
\text { IVProbit }\end{array}$ & $\begin{array}{c}(3) \\
\text { Probit }\end{array}$ & $\begin{array}{c}(4) \\
\text { IVProbit }\end{array}$ & $\begin{array}{c}(5) \\
\text { Probit }\end{array}$ & $\begin{array}{l}(6) \\
\text { IVProbit }\end{array}$ & $\begin{array}{c}(7) \\
\text { Probit }\end{array}$ & $\begin{array}{c}(8) \\
\text { IVProbit }\end{array}$ & $\begin{array}{c}(9) \\
\text { Probit }\end{array}$ & $\begin{array}{c}(10) \\
\text { IVProbit }\end{array}$ \\
\hline Migrant household & $\begin{array}{c}0.065 \\
(3.21)^{* *}\end{array}$ & $\begin{array}{c}0.300 \\
(13.26)^{* *}\end{array}$ & $\begin{array}{l}-0.017 \\
(2.51)^{*}\end{array}$ & $\begin{array}{c}-0.192 \\
(5.56)^{\star *}\end{array}$ & $\begin{array}{l}-0.027 \\
(1.49)\end{array}$ & $\begin{array}{c}-0.363 \\
(8.09)^{* *}\end{array}$ & $\begin{array}{l}-0.000 \\
(0.01)\end{array}$ & $\begin{array}{c}-0.108 \\
(2.58)^{\star *}\end{array}$ & $\begin{array}{c}-0.002 \\
(3.08)^{* *}\end{array}$ & $\begin{array}{l}-0.005 \\
(2.70)^{* *}\end{array}$ \\
\hline Mother's age & $\begin{array}{l}0.005 \\
(0.98)\end{array}$ & $\begin{array}{r}-0.002 \\
(0.39)\end{array}$ & $\begin{array}{c}0.010 \\
(2.92)^{\star *}\end{array}$ & $\begin{array}{c}0.012 \\
(4.08)^{\star *}\end{array}$ & $\begin{array}{l}-0.006 \\
(1.33)\end{array}$ & $\begin{array}{l}-0.002 \\
(0.57)\end{array}$ & $\begin{array}{c}0.040 \\
(7.20)^{\star *}\end{array}$ & $\begin{array}{c}0.041 \\
(8.99)^{* *}\end{array}$ & $\begin{array}{l}0.000 \\
(0.34)\end{array}$ & $\begin{array}{l}0.000 \\
(0.63)\end{array}$ \\
\hline Mother's age squared & $\begin{array}{l}-0.000 \\
(0.16)\end{array}$ & $\begin{array}{l}0.000 \\
(0.92)\end{array}$ & $\begin{array}{l}-0.000 \\
(3.28)^{\star *}\end{array}$ & $\begin{array}{l}-0.000 \\
(4.42)^{\star *}\end{array}$ & $\begin{array}{l}0.000 \\
(1.58)\end{array}$ & $\begin{array}{l}0.000 \\
(1.05)\end{array}$ & $\begin{array}{c}-0.001 \\
(6.14)^{\star *}\end{array}$ & $\begin{array}{c}-0.001 \\
(7.39)^{\star *}\end{array}$ & $\begin{array}{r}-0.000 \\
(0.11)\end{array}$ & $\begin{array}{r}-0.000 \\
(0.39)\end{array}$ \\
\hline Mother's years of schooling & $\begin{array}{c}0.040 \\
(19.19)^{\star *}\end{array}$ & $\begin{array}{c}0.039 \\
(29.50)^{* *}\end{array}$ & $\begin{array}{r}-0.001 \\
(0.85)\end{array}$ & $\begin{array}{l}-0.001 \\
(0.75)\end{array}$ & $\begin{array}{c}0.024 \\
(13.18)^{* *}\end{array}$ & $\begin{array}{c}0.024 \\
(20.21)^{\star *}\end{array}$ & $\begin{array}{c}-0.001 \\
(0.96)\end{array}$ & $\begin{array}{l}-0.001 \\
(1.09)\end{array}$ & $\begin{array}{c}-0.000 \\
(3.36)^{\star *}\end{array}$ & $\begin{array}{l}-0.000 \\
(4.43)^{\star *}\end{array}$ \\
\hline Household Size & $\begin{array}{c}-0.017 \\
(10.80)^{\star \star}\end{array}$ & $\begin{array}{c}-0.019 \\
(13.58)^{\star *}\end{array}$ & $\begin{array}{c}0.003 \\
(2.33)^{*}\end{array}$ & $\begin{array}{c}0.003 \\
(3.26)^{* *}\end{array}$ & $\begin{array}{c}-0.011 \\
(7.42)^{\star *}\end{array}$ & $\begin{array}{l}-0.010 \\
(7.43)^{\star \star}\end{array}$ & $\begin{array}{c}-0.010 \\
(6.47)^{\star *}\end{array}$ & $\begin{array}{c}-0.010 \\
(6.50)^{\star *}\end{array}$ & $\begin{array}{r}-0.000 \\
(0.73)\end{array}$ & $\begin{array}{l}-0.000 \\
(0.86)\end{array}$ \\
\hline State-level controls & yes & yes & yes & yes & yes & yes & yes & yes & yes & yes \\
\hline Observations & 14803 & 14803 & 14571 & 14571 & 14079 & 14079 & 13989 & 13989 & 24865 & 24865 \\
\hline
\end{tabular}

Notes:

Robust t-statistics in parentheses clustered at the state level

Coefficients for the probit are marginal effects giving the discrete change in the probability of the given health input

for a migrant household, and the change in the probability for infinitesimal changes in the other variables.

1924 state migration rate is used as instrument for being in a migrant household

State level controls are 1930 infant mortality rate, health infrastructure, and 1997 GDP per capita.

All vaccines includes tuberculosis, DPT, Polio and Measles

* significant at $5 \%$; ** significant at $1 \%$ 
Table 8: The Impact of Migration on Maternal Health Knowledge Dependent variable: Maternal health knowledge index

\begin{tabular}{|c|c|c|c|c|c|c|c|c|}
\hline & $\begin{array}{l}\text { (1) } \\
\text { OLS }\end{array}$ & $\begin{array}{c}(2) \\
2 S L S\end{array}$ & $\begin{array}{l}\text { (3) } \\
\text { OLS }\end{array}$ & $\begin{array}{c}(4) \\
2 S L S\end{array}$ & $\begin{array}{c}\text { (5) } \\
\text { OLS }\end{array}$ & $\begin{array}{c}(6) \\
2 S L S\end{array}$ & $\begin{array}{l}(7) \\
\text { OLS }\end{array}$ & $\begin{array}{c}(8) \\
2 S L S\end{array}$ \\
\hline Migrant household & $\begin{array}{c}0.266 \\
(4.01)^{* *}\end{array}$ & $\begin{array}{c}1.289 \\
(2.61)^{* *}\end{array}$ & & & & & & \\
\hline Mother has migrated & & & $\begin{array}{c}0.473 \\
(4.41)^{* *}\end{array}$ & $\begin{array}{c}4.853 \\
(2.45)^{\star}\end{array}$ & & & & \\
\hline Father has migrated & & & & & $\begin{array}{c}0.238 \\
(3.37)^{\star *}\end{array}$ & $\begin{array}{c}1.290 \\
(2.51)^{*}\end{array}$ & & \\
\hline $\begin{array}{l}\text { Proportion of migrant households } \\
\text { in municipality }\end{array}$ & & & & & & & $\begin{array}{l}0.519 \\
(1.81)\end{array}$ & $\begin{array}{c}1.272 \\
(3.07)^{\star *}\end{array}$ \\
\hline Observations & 12744 & 12744 & 10676 & 10676 & 12489 & 12489 & 6135 & 6135 \\
\hline
\end{tabular}

Notes:

Regressions are for women aged 15-54 who gave birth between 1994 and 1997 and were the household head or spouse of the household head.

Columns 7 and 8 are for these women in non-migrant households in municipalities with 50 or more total households surveyed.

All regressions also include a quadratic in mother's age, mother's years of schooling, household size 1930 infant mortality rate, health infrastructure, and 1997 GDP per capita and a constant.

Robust t-statistics in parentheses clustered at the state level

* significant at $5 \%$; ** significant at $1 \%$ 
Table 9: How does migration improve health outcomes?

\begin{tabular}{|c|c|c|c|c|}
\hline & $\begin{array}{l}\text { Infrastructure } \\
\text { Index } \\
(1) \\
\text { 2SLS }\end{array}$ & $\begin{array}{l}\text { Health Knowledge } \\
\text { Index } \\
(2) \\
\text { 2SLS }\end{array}$ & $\begin{array}{c}\text { Infant mortality } \\
\text { (non-migrant hhs) } \\
(3) \\
\text { Probit }\end{array}$ & $\begin{array}{c}\text { Birthweight } \\
\text { (non-migrant hhs) } \\
\text { (4) } \\
\text { OLS }\end{array}$ \\
\hline Migrant household & $\begin{array}{c}3.196 \\
(3.83)^{\star \star}\end{array}$ & $\begin{array}{c}1.300 \\
(2.48)^{\star}\end{array}$ & & \\
\hline Mother's age & $\begin{array}{l}0.004 \\
(0.19)\end{array}$ & $\begin{array}{c}0.163 \\
(7.12)^{\star \star}\end{array}$ & $\begin{array}{l}-0.001 \\
(0.47)\end{array}$ & $\begin{array}{l}0.019 \\
(2.03)\end{array}$ \\
\hline Mother's age squared & $\begin{array}{l}0.000 \\
(1.57)\end{array}$ & $\begin{array}{c}-0.002 \\
(5.57)^{\star \star}\end{array}$ & $\begin{array}{l}0.000 \\
(0.50)\end{array}$ & $\begin{array}{l}-0.000 \\
(1.18)\end{array}$ \\
\hline Mother's years of schooling & $\begin{array}{c}-0.065 \\
(5.69)^{\star *}\end{array}$ & $\begin{array}{c}-0.073 \\
(7.07)^{\star *}\end{array}$ & $\begin{array}{l}-0.001 \\
(1.95)\end{array}$ & $\begin{array}{l}-0.004 \\
(1.53)\end{array}$ \\
\hline Household Size & $\begin{array}{c}0.268 \\
(30.94)^{\star *}\end{array}$ & $\begin{array}{c}0.192 \\
(17.03)^{\star *}\end{array}$ & $\begin{array}{l}-0.001 \\
(2.37)^{\star}\end{array}$ & $\begin{array}{l}0.001 \\
(0.39)\end{array}$ \\
\hline Health Knowledge Index & & & $\begin{array}{l}-0.001 \\
(1.95)\end{array}$ & $\begin{array}{c}0.014 \\
(3.61)^{\star *}\end{array}$ \\
\hline Infrastructure Index & & & $\begin{array}{l}-0.001 \\
(1.62)\end{array}$ & $\begin{array}{c}0.015 \\
(4.04)^{\star *}\end{array}$ \\
\hline state-level controls & yes & yes & yes & yes \\
\hline Observations & 16193 & 16527 & 12966 & 9322 \\
\hline
\end{tabular}

Notes:

Probit coefficients are marginal effects

State level controls are 1930 infant mortality rate, health infrastructure, and 1997 GDP per capita.

Robust t-statistics in parentheses clustered at the state level

${ }^{*}$ significant at $5 \%$; ${ }^{* *}$ significant at $1 \%$ 
Table A1: Principal component for health knowledge index

\begin{tabular}{lccc}
\hline Contraceptive Practice & $\begin{array}{c}\text { Scoring } \\
\text { Factor }\end{array}$ & Mean & Std. Dev. \\
\hline Birth control pill & 1.549 & 0.947 & 0.224 \\
Condom & 1.105 & 0.874 & 0.331 \\
Diaphragm or Sponge & 0.511 & 0.420 & 0.494 \\
Intrauterine Device (IUD) & 1.327 & 0.925 & 0.263 \\
Injection & 1.286 & 0.915 & 0.278 \\
Norplant implant & 0.428 & 0.125 & 0.331 \\
Tubal Occlusion & 1.154 & 0.901 & 0.299 \\
Vasectomy & 0.842 & 0.767 & 0.423 \\
Natural Family Planning & 0.634 & 0.610 & 0.488 \\
Withdrawal & 0.535 & 0.499 & 0.500 \\
& & & \\
Eigenvalue of 1st component & 3.944 & & \\
Share of variance explained & 0.394 & & \\
\hline
\end{tabular}

Notes: scoring factors are divided by the standard deviation, and give the effect of a change from 0 to 1 on the index. 